\title{
Efficiency the Utilization of Folow up Palm Plants foor Increasing Production Beef Cattle in District Pasaman Barat
}

\author{
Rahmi Wahyuni ${ }^{1, *}$, R.A. Dewi ${ }^{1}$, Harmaini ${ }^{1}$, and $S$. Asmairicen ${ }^{1}$ \\ ${ }^{1}$ Balai Pengkajian Teknologi Pertanian Sumatera Barat.
}

\begin{abstract}
The main problem in the development of cattle business people in palm plantation, one exeption availibility of forage animal feed whether in quantity $\mathrm{n}$ quality. Other side the existence of palm leaves the midrib has been waste of a disturbing and not been utilized by farmers. To the touch technological innovations feed in te form of silage then palm leaves the midrib has been animal feed worthy of in eating of cattle. The purpose of this research is identify the effects the provisio of feed based silage palm leaves midrib increased body weight on cattle beef and analyzing efficiency the cost of animal feed. Research in farmer group Tanjung Keramat in district Kinali, Pasaman Barat in february until april 2017. Respondent are set down in purposive sampling. This research used 18 tail local bulls created the average 2 until 2, 5 years. Treatment provides was P1 control grass field is $10 \%$ from body weght $(25 \mathrm{Kg})+$ bran is $10 \%$ from body weght $(2,5 \mathrm{Kg}), \mathrm{P} 2$ granting of silage then palm leaves $(10 \mathrm{~kg})+$ bran $(1,5 \mathrm{Kg})+$ gliserida $(2 \mathrm{Kg})$. In an analysis using $\mathrm{t}$ tableindependent sample $t$-test $\alpha=5 \%$. Result of research shows P1 increase body weight cattle $0,68 \mathrm{~kg} /$ tail $/$ day and $\mathrm{P} 20,81 \mathrm{~kg} /$ tail/ day . Provision of feed based silage then palm leaves significant compared feed control $t$ test $(-6,9)>t$ tabel $(2,4)$. With efficiency cost feed during 90 days P1 (Rp. 967.500,-/ tail) and P2 (Rp. 675.500,-/tail). So, with provision palm leaves besides increasing body weight cattle, can also reducing the grass that drain time dan energy can reduce the cost daily cattle feed.
\end{abstract}

Keyword : beef cattle, feed, palm leaves

\section{Introduction}

Farm is one of the superior sectors in terms of increasing income an area,as always high demand for livestock products as meat, milk, eggs and others. Their This to the livestock sector is an opportunity to further develop animal husbandry to livestock area. But in reality farm businees is dominated by holder livestock, where is the farmers have many limitations like in terms of, ownership forage limited information, the limited human resources, and limited capital. In farm the most important thing to keep the sustainability of farm businees, one of them is the availability of fodder and forage fodder both in quality.

*Corresponding author: bundanayla26@gmail.com 
This is because the land transfer function from forage land pasture fattening to be the agriculture, industry and settlement.

[17-18] says one of the solution to always keep going to the needs of the availability of feed them with the use of specific location an agriculture waste. In general to waste food crops many known and used the feed as straw corn and hay rice. But to farmemrs who are based on the site of the oil palm having obtacles in fulfiling the availability of forage fodder, because forage in land borders of the oil palm very limited. Therefore the need for utilization of waste the oil palm like the midrib palm leaves that as long as it is disturbing in land palm $[2,8,9,11,12]$. To the touch technological innovations fodder such as silage or fermentation midrib palm leaves can be processed to silage midrib palm leaves whose nutrition having the similar with forage fodder so able to replace forage as fodder. According to $[3,14,15]$, there needs to be a touch of technological innovations in agricultural waste to increase the value of nutrientswith the addition of an enzyme, growing mushrooms, and bacteria and anaerobic fermentation.

Based on the existing potential west Sumatera get garden enough the oil palm widely reaching 129.93720 ha. In district pasaman there are of the oil palm is 66.337 ha. Potentially highly prospective oil palm plantations bearing in mind the $70 \%$ from remainig agrocultural ( midrib, leaves and stems) can be used as a source of forage [1]. Ny tree palm produce $22 \mathrm{midrib} /$ year with weights $7 \mathrm{~kg}$. If every hectares of land planted 130 tree so obtained 20.020 fresh midrib/ years. Mindrib contains 26,1\% dry substances or $5.270 \mathrm{~kg} /$ ha that is easily digested by a cow.

The utilization on waste the oil palm an efficiency move produced feed that are able to increase productivity cattle. Capacity a garden the oil palm in west sumatera to give contribution to development of beef catle industry have promising prospect in West Sumatera. The purpose of this research is identify the effects the provisio of feen based silage palm leaves midrib increased body weight on cattle beef and anilize efficiency the cost of animal feed at Tanjung Keramat Groups in Sub- district Kinali district West Pasaman.

\section{Methodology}

Research implemented at Tanjung Keramat groups in sub district Kinali district West Pasaman on the February - March 2017. Responden appointed purposive sampling. Collection of data using recording at regular interval to see growth of weight cattle. Collection data was done with technique with assistance teams for technological innovations feed midrib based silage palm leaves. Cattle kept during research do with cage system. This research uses 18 tail the bull with avarage age of $2-2,5$ years. Treatment that given is P1 control pattern $10 \%$ grass field from weight $(25 \mathrm{~kg})+$ bran $1 \%$ from weight ( $2,5 \mathrm{~kg}), \mathrm{P} 2$ give silage palm leaves $(10 \mathrm{Kg})+\operatorname{bran}(1,5 \mathrm{Kg})+$ glyceride $(2 \mathrm{~kg})$.

\subsection{Methods of Analysis}

Tabulation and analysis implemented by descriptive set qualitative and quantitative. Data of collection is growth of weight beef cattle and data of cost efficiency fodder needs during research. For data impact give silage palm leaves to weight beef cattle used independent sample $t$-test $(\alpha=5 \%)$. Before implemented testing, the first known varians from two data. Testing varians data is $: F=\left(\mathrm{S}_{1}\right)^{2} /\left(\mathrm{S}_{2}\right)$

$$
\begin{aligned}
& \mathrm{F}=\mathrm{F} \text { value } \\
& \mathrm{S}_{1}=\text { Large varians value } \\
& \mathrm{S}_{2}=\text { Small varians value }
\end{aligned}
$$


Data has equal variance if F-value $<$ F-Table and instead unequal variance if F-value $>$ F-Table. T-test for equal variance used formula Polled Varians:

$$
\begin{gathered}
\text { T-test for unequal vari } t=\frac{\bar{X}_{1}-\bar{X}_{2}}{\sqrt{\frac{\left(n_{1}-1\right) S_{1}^{2}+\left(n_{2}-1\right) S_{2}^{2}}{n_{1}+n_{2}-2}\left(\frac{1}{n_{1}}+\frac{1}{n_{2}}\right)}} \\
\quad t=\frac{\bar{X}_{1}-\bar{X}_{2}}{\sqrt{\frac{S_{1}^{2}}{n_{1}}+\frac{S_{2}^{2}}{n_{2}}}} \\
\quad \begin{array}{l}
\mathrm{X}=\text { Average Value } \\
\mathrm{S}_{1}=\text { Large varians value } \\
\mathrm{S}_{2}=\text { Small varians value }
\end{array}
\end{gathered}
$$

For data cost efficiency fooder based silage palm leaves analyzys used data tabulation and persentage.

\section{Results And Discussion}

\subsection{Growth of Body Weight of Beef Cattle}

The feed assistance that has been given to livestock in the Saiyo Sakato group is in the form of control feed (P1) and palm leaf midrib silage based feed (P2). Utilization of palm oil waste such as palm leaf midrib is a feed that has the potential to increase livestock body weight, which can be seen in the graph below.

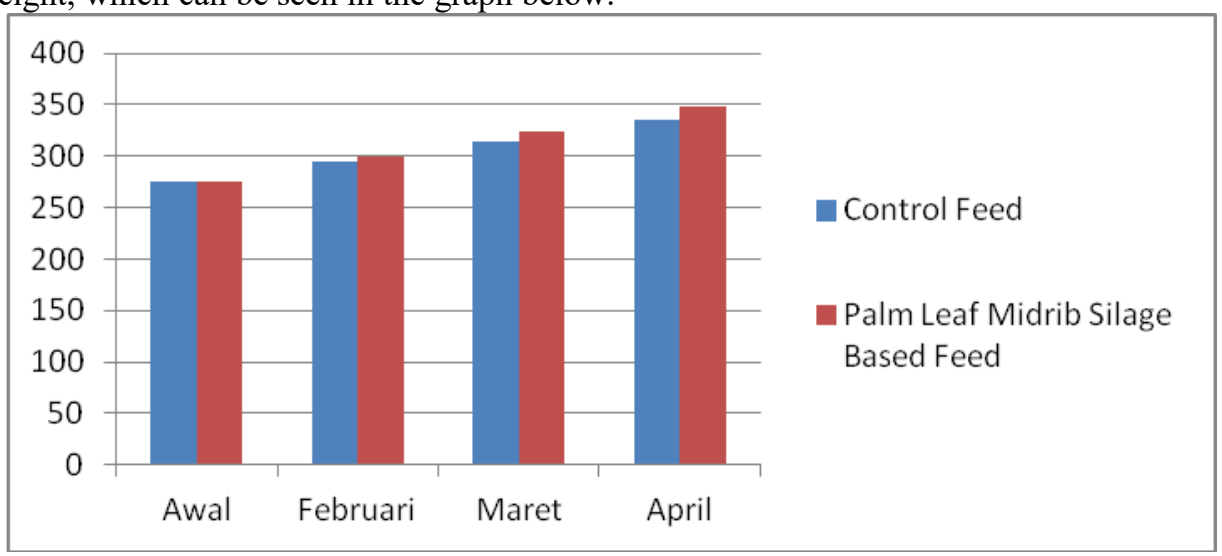

Fig. 1. Average Weight Gain Of Beef Cattle

The chart above shows (p1) raising heavy bodies cattle production $0,68 \mathrm{~kg} /$ tail / day and p2 0,81 kg / tail / Day. [7] mentioned that by-product palm oil can be used as animal feed ruminants among others the midrib, palm leaves bunches of empty, palm oil mud bungkil oil palm and palm kernel. Midrib palm leaves obtained from trimming can forage mensubsitusi cattle. Shortage cattle farmers to midrib leaves for palm than have grass midrib palm easy because leaves in extract palm especially in gardens during harvest time. Midrib one bunches of palm that is pared his skin can reaches the weight of 2,2 kg.Farmers more saves time and so is, with the coarse palm protein midrib $(9,22 \%)$ higher than grass $(8,2 \%)[4,16]$ midrib palm is a source of forage for cattle for forage mensubstitusi feed. [6] stated that the number of feed consumption a decisive factor the most important in determining the amount of food substances obtained by cattle. To see whether control 
pattern feed (P1) and palm-based feed (P2) have a significant effect or not, we can see the data below.

t-Test: Paired Two Sample for Means

\begin{tabular}{lrr}
\hline & $p 1$ & $p 2$ \\
\hline Mean & 0,688571429 & 0,81 \\
Variance & 0,007414286 & 0,009566667 \\
Observations & 7 & 7 \\
Pearson Correlation & $-0,186020849$ & \\
Hypothesized Mean Difference & 0 & \\
Df & 6 & \\
t Stat & $-6,929023282$ & \\
P $(\mathrm{T}<=\mathrm{t})$ one-tail & 0,000223767 & \\
t Critical one-tail & 1,943180274 & \\
P $(\mathrm{T}<=\mathrm{t})$ two-tail & 0,000447535 & \\
$\mathrm{t}$ Critical two-tail & 2,446911846 & \\
\hline
\end{tabular}

Source: Processed data, 2020

From the analysis, it can be seen that there is a $t$ stat with a value of -6.9 . The value of $t$ Stat is the value of $t$ count. The $t$ table value is shown by the Critical Two-tail $t$ with a value of 2.44 . So $t$ count $(-6,9)>t$ table $(2,4)$. This means that oil palm waste-based feeding is significantly different compared to farmer pattern feed. So feed based waste palm capable of promote the country the weight increased productivity increase cattle, and long term for support beef development in West Sumatera.

Research results [13], shows that leaves silage midrib palm as fodder containing nutritional value high and the palm midrib leaves as the substitution forage feed beef can be given all the way up to $60 \%$, and will improve the weight cattle production compared to be forage and more efficient in the use of feed. According to [5], palm fronds and leaves can be used as cattle feed instead of grass as a source of forage, because they have high crude fiber with high lignin levels, $17.4 \%$ and $27.6 \%$.

\subsection{Cost Efficiensy Fooder Beef Cattle}

In this research used fooder control pattern (P1) andfooder based silage palm leaves (P2), that has fooder cost different. Fooder issued during the research ( 90 days) can be seen in table below :

Table 1. The Provision Of Feed At Treatment 1 (1 tail/days).

\begin{tabular}{lccc}
\hline Ingredients & Amount $(\mathrm{kg})$ & Price $/ \mathrm{kg}$ & Cost $(\mathrm{Rp})$ \\
\hline Grass Field & 25 & 300 & 7.500 \\
Bran & 2,5 & 1.300 & 3.250 \\
\hline Total cost & - & - & 10.750 \\
\hline
\end{tabular}

Source : Primary Data, 2017

Table 2. The Provision Of Feed At Treatment 2 (1 tail/days).

\begin{tabular}{lccc}
\hline Ingredients & Amount $(\mathrm{kg})$ & Price $/ \mathrm{kg}$ & Cost $(\mathrm{Rp})$ \\
\hline Palm leaves & 10 & 500 & 5000 \\
bran & 1,5 & 1.300 & 1.950 \\
glyceride & 2 & 300 & 600 \\
\hline Total cost & - & - & 7.550 \\
\hline
\end{tabular}

Source : Primary Data, 2017 
Table 3. Cost Efficiency Fooder Based Silage Palm Leaves (1 tail/90 days).

\begin{tabular}{|c|c|c|c|c|c|}
\hline \multirow[t]{2}{*}{ Treatment } & \multirow{2}{*}{$\begin{array}{c}\text { Selling Price } \\
\text { (Rp/tail) }\end{array}$} & \multirow{2}{*}{$\begin{array}{l}\text { Purchase } \\
\text { Price } \\
\text { (Rp/ekor) }\end{array}$} & \multirow{2}{*}{$\begin{array}{c}\text { Fooder } \\
\text { Cost }^{1)} \\
(\mathrm{Rp})\end{array}$} & \multicolumn{2}{|c|}{ Benefit/Tail $^{2)}$} \\
\hline & & & & (Rp) & $(\%)^{3)}$ \\
\hline $\mathrm{I}$ & 6.500 .000 & 8.250 .000 & 967.500 & 782.500 & 100 \\
\hline II & 6.500 .000 & 8.750 .000 & 675.500 & 1.574 .500 & 174,7 \\
\hline
\end{tabular}

Source: Processed Primary Data, 2020.

Description : ${ }^{1)}$ Cost Fooder during 90 days; ${ }^{2}$ Bennefit= differencesell- purchase be reduced cost fooder; ${ }^{3)}$ Treatment 1 by contrast.

With efficiency fooder cost during 90 days achieve $43 \%$ to reduce fooder cost is P1 Rp. 967.500,-/tail and P2 Rp. 675.500,-/tail. And profitability P1 (100\%0) as control and fooder based silage palm leaves P2 (174,7\%), as benefit promising. So, with give palm leaves and to increase weight beef cattle, can also reduced used grass that drain time and energy and can reduce fooder beef cattle.

\section{Conclusion}

Result of research shows P1 increase body weight cattle $0,68 \mathrm{~kg} /$ tail/day and P2 $0,81 \mathrm{~kg} /$ tail/ day.Provision of feed based silage then palm leaves significant compared feed control $t$ test $(-6,9)>t$ tabel $(2,4)$. With efficiency cost feed during 90 days P1 (Rp. 967.500,-/ tail) and P2 (Rp. 675.500,-/tail). So, with provision palm leaves besides increasing body weight cattle, can also reducing the grass that drain time dan energy can reduce the cost daily cattle feed.

\section{Reference}

1. Azmi dan Gunawan. Pemanfaatan Pelepah Kelapa Sawit dan Solid untuk Pakan Sapi Potong. Seminar Nasional Peternakan dan Veteriner. Pusat Penelitian dan Pengembangan Pertanian (2005).

2. Djajanegara, A. B., Sudaryanto. M., Winugroho dan A. R. A. Karto. Potensi produk kebun kelapa sawit untuk pengembangan usaha ternak ruminansia. Laporan APBN 1998/1999. Balai Penelitian Ternak, Puslitbang Peternakan, Bogor (1999).

3. Elihasridas, M. Zain., Y. Marlida., \& Andri. Effect of the Level of Energy and Dietary Protein of Ammoniated Rice Straw on the Productivity of Male Simmental Cattle in a Tropical Area. Pak. J. Nutr., 18 (1): 60-66 (2019).

4. Fakhri Syahruddin. 2006. Pembangunan Peternakan Masyarakat Secara Terpadu Menuju Swasembada Daging. Pros. Seminar Nasional Peternakan Badan Litbang Pertanian/BPTP Sumatera Barat, Padang 11-12 September 2006.(2010).

5. Gunawan dan Talib, C. 2014. Potensi Pengembangan Bioindustri Dalam Sistem Integrasi Sapi Sawit. WARTAZOA Vol 24. No 2. Hal 67-74.(2010).

6. Mariam, T. Perbedan Pertambahan Bobot Badan, Konsumsi dan Efisiensi Pakan Antara Sapi Jantan PO Dengan Fries Holand Dalam Kondisi Peternakan Rakyat. Skripsi. Fakultas Peternakan, Universitas Padjajaran, Bandung (2004).

7. Mathius, I,W., Azmi, B.P. Manurung, D.M. Sitompul dan Eko Priyatno. Integrasi Sapi-Sawit: Imbangan Pemanfaatan Produk Samping sebagai Bahan Dasar Pakan. Prosiding Seminar Integrasi Tanaman Ternak. Denpasar 20-22 Juli 2004. Hal: 439446.(2004). 
8. Nurhaita, N. Jamarun, R. Saladin, L Warly dan Mardiati Z. Efek suplementasi mineral Sulfur dan Phospor pada daun sawit amoniasi terhadap kecernaan zat makanan secara in-vitro dan karakteristik cairan rumen. J. Pengembangan Peternakan Tropis 33(1): 51-58. (2008).

9. Nurhaita, N Jamarun, L Warly, dan M, Zain. Kecernaan Ransum Domba Berbasis Daun Sawit Teramoniasi Yang Disuplementasi Sulfur, Fosfor, Dan Daun Ubi Kayu. Jurnal Media Peternakan. Vol 33 No 3.(2010).

10. Nurhaita, Ruswendi, dan Wismalinda R. Pemanfaatan Limbah Pelepah Sawit Untuk Pakan Komplit Sapi Potong Dengan Suplementasi Nutrient Precursor Mikroba Rumen. Laporan Penelitian KKP3T, Badan Litbang Pertanian Jakarta dan Fakultas Pertanian Universitas Muhammadiyah Bengkulu (2011).

11. Nurhaita, Ruswend., Wismalinda R. dan Robiyanto. Pemanfaatan Pelepah Sawit Sebagai Sumber Hijauan dalam Ransum Sapi Potong. Jurnal pastura Vol. 4 No. 1 : 38 - 41.(2014).

12. Nurhaita, Definiati N, Feni R. Utilization Of Complete Feed Base Oil Palm Waster For Kurban Fattening On Kelompok Tani Ternak Sumber Rezeki). Sinar Sang Surya 3 (1): 1-7.(2019).

13. Pranata dan Arico. Utilization of Palm Oil (Elaeis guinensis Jacq) Garden Midribs Waste As an Alternative of High Nutritioned Livestock Feed.Jurnal Biologica Samudra 1(1): 17-24. (2019).

14. Rauf, J. Potensi Limbah Tanaman Pangan Sebagai Sumber Pakan Dalam Pengembangan Ternak Sapi Potong. Tesis.(2013)

15. Rauf, J. dan Rasbawati. Kajian Potensi Limbah Pertanian Sebagai Pakan Ternak Sapi Potong di Kota Pare-Pare. Jurnal Galung Tropika. 4 (3): 173-178.(2015).

16. Sitompul, D. Desain pembangunan kebun dengan system usaha terpadu ternak sapi Bali. Prosiding Lokakarya Nasional: Sistem Integrasi Kelapa Sawit-Sapi. Bengkulu 910 September 2003. P. 81-88.(2003).

17. Suherman, \& Kurniawan, E. Manajemen Pengelolaan Ternak Kambing di Desa Batumilasebagai pendapatan tambahan petani lahan kering. Jurnal Dedikasi Masyarakat, 1(1), 7-13.(2017).

18. Syamsu, J.A. Optimalisasi Pemanfaatan Limbah Pertanian Sebagai Pakan Sapi Potong di Peternakan Rakyat. Prosiding Seminar Nasional Inovasi Teknologi Peternakan dalam Mendukung Terwujudnya Ketahanan Pangan Nasional. Fakultas Peternakan Universitas Halu Oleo, Kendari, 17 November 2018. hal. 1-10. (2018). 